\title{
Környezetvédelmi közvetítés Németországban
}

\author{
közvetítés - környezetvédelem - beruházások - döntéshozatal - Németország
}

A közvetítői eljárás, más néven mediációs eljárás célja, hogy a feleknek lehetőséget biztosítson arra, hogy a jogszabályok merev alkalmazása helyett egy közös és kölcsönösen elönyös megoldást találjanak konfliktusuk rendezésére. Németországban a közvetítői eljárás fogalmát a közvetítő eljárásról szóló törvény tartalmazza. E törvény megfogalmazásában a közvetítés egy jól felépített bizalmi eljárás, mely során a felek egy vagy több közvetítő segítségével önkéntes alapon és önállóan egy olyan megoldás kidolgozására törekszenek, mely kölcsönösen előnyös számukra. ${ }^{1}$

A környezetvédelmi közvetítés egy olyan strukturált konfliktusrendezési eljárás, melyet egy képzett mediátor vezet, aki a felekkel közösen a felmerülö környezeti konfliktus rendezésén dolgozik. ${ }^{2}$ Egy másik megfogalmazás szerint a környezetvédelmi közvetítés a konfliktusok rendezésének szisztematikus és strukturált formája, mely során egy professzionális közvetítő a konfliktus feloldását széles körben, így eljárásilag és pszichológiailag egyaránt támogatja azzal a céllal, hogy a problémára mindenki számára megfelelö, de legalább elfogadható megoldás szülessen. ${ }^{3}$ Talán első olvasatra a fenti fogalommeghatározások alapján úgy tünhet, hogy nincs jelentős különbség a két közvetítöi eljárás között, azonban ez korántsem igaz.

Az előzőekben definiált közvetítői eljárások azonban sok szempontból különböznek egymástól. Egy olyan közvetítői eljárást, mely a vitában érintett két fél és egy közvetítő részvételével eljárási szempontból szabadon zajlik, aligha lehet azonosnak tekinteni egy olyan közvetítői eljárással, mint a környezetvédelmi érdekeket szem elött tartó közvetítés. A közvetítői eljárásról szóló törvény által definiált közvetítöi eljárást, mely a polgári jog körében felmerült jogviták feloldására hivatott, hagyományos közvetíői eljárásnak nevezem.

Jelen tanulmány bemutatja, hogy milyen megfontolások vezettek a környezetvédelmi közvetítés megjelenéséhez Németországban, és feltárja az intézmény történeti vonatkozásait. A tanulmány ezt követöen sorra veszi a környezetvédelmi közvetítés jellemzőit abból a célból, hogy bemutassa, milyen eltérő követelmények és eljárásrend tartozik a környezetvédelmi közvetítéshez a közvetítés hagyományos típusához képest.

* Dr. Bereczki István fogalmazó, Debreceni Törvényszék; PhD-hallgató, Debreceni Egyetem Állam- és Jogtudományi Kar Marton Géza Állam- és Jogtudományi Doktori Iskola. bereczki.jb@gmail.com.

1 Mediationsgesetz vom 21. Juli 2012 (BGBI. I S. 1577) 1. §.

2 Овотн, Monika-WeCKERT, Al: Mediation für Dummies. WILEY-VCH Verlag GmbH \& Co. KGaA, Weinheim, 2014, 14.

3 Flucher, Thomas-Kochendörfer Bernd-Minckwitz, Ursula-Viering, Markus: Mediation im Bauwesen. Ernst \& Sohn, Berlin, 2003, 98. 


\section{A környezetvédelmi közvetítés megjelenése Németországban}

\subsection{A környezetvédelmi közvetítés megjelenésének egyes kérdéseiröl}

Egy nagyszabású beruházás kapcsán, mely emberek jelentős csoportját érinti, rengeteg kérdés és probléma merül fel, melynek politikai, szociális, környezetvédelmi és számos más egyéb vetülete lehet. Nagyszabású beruházás alatt érthető például útépítés, hulladéklerakó létesítése, de akár egy repülötér-bővítés is. A környezetvédelemmel kapcsolatos kérdésekben, különösen a sürün lakott területeken, igen nagy kihívást jelent olyan megoldás kidolgozása, mely hatékony és egyúttal társadalmilag széles körben elfogadott. Elég ezen a ponton arra utalni, hogy a társadalomnak különféle csoportjai vannak, melyek eltérő értékekkel, érdekekkel és elvárásokkal közelítenek meg egyes kérdéseket. ${ }^{4}$ Amikor egy projekt, nagyberuházás hatással van a környezetre, mindig nagy körültekintéssel kell eljárni, hiszen a megvalósítás közvetlenül érinti az emberek életét, és ezért az elfogadható kockázatok körének meghatározása nagy kihívást jelent. Nehéz továbbá meghatározni az érintettek körét, illetve azok érdekeit. Ezeken a területeken jellemző, hogy majdnem minden projekt kapcsán markáns ellenzék alakul ki. Hevesen egymásnak feszülhetnek ugyanis a befektetök és projektfejlesztök érdekei az egyéni, illetve lakossági érdekekkel. Ezenfelül általában politikailag is erősen terheltek ezek a konfliktusok, és gyakran hatóságok is érdekeltté válnak. Ezek a konfliktusok a tervezési és engedélyezési szakasz során kifogások formájában mutatkoznak meg, melyek lassítják a folyamatot, a konzultációs szakaszban pedig heves és már-már erőszakos viták formájában jelentkeznek. A döntéshozatali eljárást továbbá gyakran nyilvános tiltakozás kíséri. Jól kifejezi a tiltakozó csoportok, illetve emberek hozzáállását a heves vitákat kiváltó projektek esetében a NIMBY kifejezés. A NIMBY a „not in my backyard” rövidítése, melynek jelentése: „ne az én portámon”. ${ }^{5} A$ kifejezés arra a hozzáállásra utal, hogy azok, akik egy egyébként gyakran közhasznúnak tekinthető beruházás kivitelezése kapcsán közvetlenül érintettek, nem az ellen tiltakoznak, hogy a projekt megvalósuljon, hanem az ellen, hogy mindez az ő érdekeik sérelmével járjon. Az érintettek olyan valós érveket hoznak fel, mint az egészségkárosodástól való félelem vagy az ingatlanuk értékcsökkenése. Általában azonban a tiltakozók is felismerik a megvalósítani kívánt projektek össztársadalmi hasznát, ami a helyzet ellentmondásos voltát adja.

A szóban forgó beruházások megvalósítása kapcsán felmerülö, környezeti relevanciával bíró kérdések nem szabályozhatók, illetve dönthetők el az érintett nyilvánosság bevonása nélkül. Az érintett nyilvánosságon az emberek azon csoportja értendő, akik a környezettel kapcsolatos döntési eljárásokban érintettek vagy valószínűleg érintettek, illetve abban érdekeltek. ${ }^{6} \mathrm{Ha}$ azonban a hatóságok mégis az

4 Mitchell, Bruce: Resource and Environmental Management. Routledge, New York, 2013, 17.

5 Falk, Gerhard-Heintel, Peter-Krainz, Ewald: Handbuch Mediation und Konflikt-management. Springer Fachmedien Wiesbaden GmbH, Wiesbaden, 2005, 220.

6 Az Európai Parlament és a Tanács (EU) 2001/92 irányelve (2011. december 13.) az egyes köz- és magánprojektek környezetre gyakorolt hatásainak vizsgálatáról. HL L 124, 25/04/15, 1-19. 
érintett nyilvánosság bevonása nélkül döntenek olyan kérdésekben, melyeknek környezeti vonatkozásai is vannak, az gyakran közigazgatási perek tucatjait vonja maga után.

A kivitelezők és döntéshozó hatóságok szintén nincsenek könnyü helyzetben: döntéseik elfogadottsága a hosszadalmas engedélyezési eljárás ellenére alacsony, az emberek gyakran elégedetlenek, ami frusztrációhoz, ${ }^{7}$ a frusztráció pedig a döntések végrehajtásának akadályozásához vezet. Talán a legfontosabb probléma a formális döntéshozatali eljárásokkal, hogy a nyilvánosság nem minden eljárási szakaszba van egyformán bevonva. ${ }^{8}$ Gyakran azt a benyomást keltik az eljárások, hogy a nyilvánosságot csupán formálisan kívánják bevonni a döntéshozatalba, és érdemi szerepet nem szánnak neki.

Németországban a különböző döntéshozatali eljárásokban, tipikusan engedélyezési eljárásokban, a részvétel lehetősége az érintett nyilvánosság számára már az 1980-as évek óta szabályozást nyert. ${ }^{9}$ Németországban számos eljárásban biztosított az érintett nyilvánosság bevonása. A teljesség igénye nélkül idesorolható a környezeti hatásvizsgálat (Umweltverträglichkeitsprüfung), illetve a stratégiai környezeti hatásvizsgálat (Strategische Umweltprüfung). ${ }^{10}$

A környezetvédelmi közvetítés az előzőekben említett eljárásokhoz hasonlóan az érintett nyilvánosság bevonását tüzi ki célul. De hogyan is javíthatja a környezetvédelmi közvetítés a környezetre hatást gyakorló beruházások kapcsán kialakult vitarendezés minőségét? A környezetvédelmi közvetítés fö célja kétségkívül a környezetvédelem. De vannak az eljárás alkalmazásának más indokai, illetve pozitív hatásai is, mint például a környezettudatosságra nevelés. Kiemelkedő előnye még az eljárásnak, hogy az egyébként gyakran támadott, általában közigazgatási hatáskörbe tartozó döntések elfogadottsági szintje nő. Ezáltal pedig nő magának a közigazgatásnak a hatékonysága. Abban az esetben, ha egy környezetvédelmi közvetítői eljárásra sor kerül, a nyilvánosság képviselői esélyt kapnak arra, hogy érdekeik szélesebb körben nyerjenek meghallgatást, mint a hagyományos döntéshozatali eljárások során. Egyes szerzők a környezetvédelmi közvetítés létjogosultságát egyenesen a jogállamiság elvéböl vezetik le, mivel álláspontjuk szerint a közvetítés a demokráciát szolgálja, ami a jogállamiság immanens kritériuma. ${ }^{11}$

Fontos kérdés, hogy a környezetvédelmi közvetítés és az alapul fekvő eljárás milyen időbeli viszonyban van egymással. Abban az esetben, ha a környezetvédelmi közvetítésre olyan idöben kerül sor, amikor annak eredménye már semmilyen befolyással nem lehet az alapul fekvő eljárásra, aligha beszélhetünk érdemi eljárásról. Így semmi esetre sem nevezhető környezetvédelmi közvetítésnek az, amikor a hatóságok már egy meghozott döntésüket akarják csupán „jóváhagyatni” a nyil-

7 http://www.uni-landau.de/umwelt/study/content/files/archiv/Bloebaum/SS09/Umweltpsychologie/Kapitel_1_ Studienbrief.pdf (2016. 11. 17.).

8 Petersen, Felicia-Zschiesche, Michael: Öffentlichkeitsbeteiligung und Umweltmediation bei großen Infrastrukturprojekten. Die Linke, Berlin, 2011, 8.

9 SCHILler, Theo: Direkte Demokratie: Eine Einführung. Campus Verlag, Frankfurt am Main, 2002, 57.

10 Petersen-Zschiesche: i. m., 24.

11 GoHL, Christopher-Hans Peter Meister: Politische Mediation bei Infrastrukturprojekten. LIT Verlag, Berlin, 2012,4 
vánosság képviselöivel, hogy később tudjanak erre a „beleegyezésre” hivatkozni. ${ }^{12}$ Elmondható, hogy a közvetítői eljárás ezen a területen nem helyettesíti a politikailag vagy jogilag meghatározott döntéshozatali eljárást. Az eljárás célja jelenleg „csupán" egy megalapozott döntés elökészítése. A közvetítés tehát ezen a területen két dolgot jelent napjainkban. Egyrészröl egy érdekorientált konfliktusrendezést, másrészről pedig emberek nagyobb mértékủ bevonását a döntéshozatalba. ${ }^{13}$ Megemlítendő azonban az is, hogy a környezetvédelmi közvetítés eredményének átvételére számos lehetőség van a gyakorlatban. llyen lehetőség például a politikai adaptáció, az engedély iránti kérelembe való átültetés vagy a terveknek a megszületett eredményeken alapuló kidolgozása. ${ }^{14}$

\subsection{A környezetvédelmi közvetítés németországi története}

A környezetvédelmi közvetítést először 1986-ban alkalmazták Németországban. Az alsó-szászországi Münchehagen városa melletti veszélyeshulladék-lerakó körül felmerült vitákat sikerült ekkor a környezetvédelmi közvetítői eljárás keretében rendezni. A konfliktus komplexitását jelzi, hogy abban tartományi szervek, közigazgatási hatóságok és az érintett nyilvánosság képviselői is részt vettek. ${ }^{15}$

A német politika azonban először "hivatalosan” csak 1993-ban vett tudomást a környezetvédelmi közvetítésröl. A nagy elörelépés az intézmény szempontjából a szövetségi kormány 1994-ben elkészített jelentése volt. Ebben a jelentésben arra tettek javaslatot, hogy a környezetvédelmi közvetítés bevezetésével egyszerüsítsék és gyorsítsák meg a káros anyagok kibocsátásának engedélyezési eljárását. ${ }^{16}$

A környezetpolitikai helyzet elemzése eredményeképpen 1996-ra arra jutott a német kormány, hogy erős ellentét van a sürgös és komplex környezetvédelmi követelmények és a fogyasztói társadalom érdekei között. ${ }^{17}$ Ezen konfliktus feloldásának szándékától vezérelve a kormány anyagi forrást bocsátott rendelkezésre abból a célból, hogy lefektessék a környezetvédelmi közvetítés alkalmazásának a pontos kritériumait. Ekkor nyilatkoztatták ki, hogy a környezetvédelemnek, illetve a környezetjognak jellegéből adódóan számos érdekkonfliktust kell kezelnie, melyre alkalmas módszer a környezetvédelmi közvetítés. ${ }^{18}$

A következő elörelépés egy bonni székhelyü környezetvédelmi munkacsoport felállitása volt. A munkacsoport összefogta a környezetpolitikai kérdések összes résztvevőjét, és szoros együttmüködést alakított ki a környezetvédelmi minisztéri-

12 http://www.uni-landau.de/umwelt/study/content/files/archiv/Bloebaum/SS09/Umweltpsychologie/Kapitel_1_ Studienbrief.pdf (2016. 11. 15.).

13 Falk-Heintel-Krainz: i. m., 220.

14 Gohl-Hans: i. m., 103.

15 http://www.umweltwissenschaften.de/fileadmin/PDF/M11_KE1_Mediation_im_oeffentlichen_Bereich_ Teil_1.pdf (2016. 11. 02.).

$16 \mathrm{http}: / /$ umweltmediation.info/menue/ueber-den-verein/vorgeschichte/ (2017. 03. 22.)

$17 \mathrm{http}: / /$ umweltmediation.info/menue/ueber-den-verein/vorgeschichte/ (2016. 11. 02.).

$18 \mathrm{http}: / /$ www.umweltwissenschaften.de/fileadmin/PDF/M11_KE1_Mediation_im_oeffentlichen_Bereich_ Teil_1.pdf (2016. 11. 02.). 
ummal is. A munkacsoport 1997-ben kezdte meg „a környezetvédelmi közvetítés átültetése Németországba" elnevezésű projektjét, melynek fő célkitűzése az volt, hogy a közvetítést meghonosítsa a környezetvédelmi aspektusokkal bíró politikai és adminisztrációs döntési mechanizmusokban. A projekt jelentős támogatásban részesült, illetve részesül mind a kormányzat, mind a magánszféra jóvoltából. A projekt levezénylése céljából létrehoztak egy a környezetvédelmi közvetítést támogató szervezetet (Förderverein Umweltmediation e.V.), mely sztenderdeket dolgozott ki a közvetítői eljárásra, illetve a közvetítők képzésére vonatkozóan. ${ }^{19} \mathrm{~A}$ munkacsoport a projektjeivel és cselekvési programjaival elösegíti a környezetvédelmi közvetítés területén zajló kodifikációs folyamatokat. ${ }^{20}$ Baden-Württemberg szövetségi tartomány 2015. január 1. napjától hatályos környezetvédelmi törvénye pedig azzal, hogy törvényi szinten szabályozza a környezetvédelmi közvetítést, azt vetíti elöre, hogy az intézmény a környezeti konfliktusok feloldásának még fontosabb eszközévé válhat a jövőben. ${ }^{21}$

A fent leírt politikai jellegü eseményekkel párhuzamosan, a gyakorlat is sokat alakított a környezetvédelmi közvetítés intézményén, illetve annak alkalmazási körén. Az alkalmazhatóság körének bővülésével egy érdekes elnevezésbeli változás is megfigyelhető.

A környezetvédelmi közvetítés útjának elején környezeti vonatkozású kérdések, illetve viták feloldására szolgált.. ${ }^{22}$ Ennek megfelelően a német elnevezése Umweltmediation, azaz környezetvédelmi közvetítés volt. Az intézmény fö alkalmazási köre ezekben az időkben a hulladéklerakó létesítmények kapcsán kialakult konfliktusok rendezése volt. Ezenfelül a kezdetektöl alkalmazást nyert az intézmény azokban az esetekben, mikor a közlekedési infrastruktúra fejlesztése vagy átalakítása hatással volt a környezetre.

Idövel azonban a környezetvédelmi közvetítést olyan területeken is elkezdték alkalmazni, mint a kereskedelmi és ipari telephelyek, szélerőművek, biogázüzemek, illetve távvezetékek telepítésével és létesítésével kapcsolatos viták. ${ }^{23}$ Mindezeken felül a környezetvédelmi közvetítés kategóriája alá kezdtek sorolni olyan vitarendezési eljárásokat is, melyek középpontjában már nem feltétlenül környezeti relevanciával bíró kérdések álltak, mint például várostervezési, illetve építési ügyek, valamint más egyéb, a városok infrastrukturális fejlesztésével kapcsolatos viták. ${ }^{24}$ Ezen a ponton azonban már megtévesztő volna a környezetvédelmi közvetítés kifejezés használata. Megjegyzendő az is, hogy például egy hulladéktároló építése kapcsán sok hatósági jogkörbe tartozó kérdés merülhet fel, melyek természetesen nem ki-

19 http://www.umweltwissenschaften.de/fileadmin/PDF/M11_KE1_Mediation_im_oeffentlichen_Bereich_ Teil_1.pdf (2016. 11. 02.).

20 http://umweltmediation.info/menue/ueber-den-verein/zielsetzung/ (2017. 03. 22.).

21 Gesetz vom 20. November 2014 zur Vereinheitlichung des Umweltverwaltungsrechts und zur Stärkung der Bürger- und Öffentlichkeitsbeteiligung im Umweltbereich 4. §.

22 FLUCHER-KOCHENDÖRFER-MINCKWITZ-VIERING: i. m., 99.

${ }^{23} \mathrm{http}: / /$ www.umweltwissenschaften.de/fileadmin/PDF/M11_KE1_Mediation_im_oeffentlichen_Bereich_ Teil_1.pdf (2016. 11. 05.).

24 http://www.umweltwissenschaften.de/fileadmin/PDF/M11_KE1_Mediation_im_oeffentlichen_Bereich_ Teil_1.pdf (2016. 11. 05.). 
zárólagosan a környezetvédelemmel kapcsolatosak. A környezetvédelmi közvetítés során sem választják le általában egy konfliktus környezetvédelmi vonatkozásait, hanem azzal együtt más kérdések megvitatására is sor kerül. Idővel a környezetjog területén zajló közvetítésre használt környezetvédelmi közvetítés kifejezést a sokkal beszédesebb „közvetítés a közszektorban” (Mediation im öffentlichen Bereich) szóhasználat váltotta fel. Ezen a ponton a téma aktualitása miatt röviden utalnék rá, hogy innen indult a napjainkban a német közigazgatási perekben zajló közvetítés története. Idővel ugyanis a „közvetítés a közszektorban” intézménye alkalmazást nyert a közigazgatási perek során is. ${ }^{25}$ Megjegyzem, hogy többségében a környezetvédelmi közvetítés kifejezést használják továbbra is Németországban, mikor a vitarendezés során környezeti hatással járó kérdések is megvitatásra kerülnek.

\section{A környezetvédelmi közvetítés mint atipikus közvetítői eljárás}

\subsection{A környezetvédelmi közvetítés jellemzői}

A környezetvédelmi közvetítés a hagyományos közvetítéstől sok szempontból eltérő, atipikus vonásokkal rendelkező közvetítői eljárás. A környezetvédelmi közvetítés sikeres alkalmazásának elengedhetetlen feltétele ezen eltérések felismerése, és az azoknak megfelelő eljárás, illetve eljárásrend kialakítása. A következőkben jelen cikk a környezetvédelmi közvetítés azon jellemzőit veszi sorra, melyek alapján megtörténhet az elhatárolás a hagyományos közvetői eljárástól.

Annak, hogy a környezetvédelem területén zajló közvetítésnek eltérő vonásai vannak, legfőképpen az az oka, hogy az alapjául szolgáló környezeti relevanciával bíró konfliktusok nagymértékben eltérnek a hagyományos közvetítés során felmerülő konfliktusoktól. Ennek a kérdéskörnek az áttekintésére hivatott az alábbi táblázat.

1. táblázat. ${ }^{26}$ Hagyományos konfliktusok - környezeti konfliktusok elhatárolása

\begin{tabular}{|l|l|l|}
\hline \multicolumn{1}{|c|}{ Vizsgálati szempont } & Hagyományos konfliktusok & \multicolumn{1}{|c|}{ Környezeti konfliktusok } \\
\hline A konfliktus jellege & $\begin{array}{l}\text { egyszerü megítélésü: kevés } \\
\text { figyelembe veendő tényező } \\
\text { és átlátható kapcsolatrend- } \\
\text { szer a felek között }\end{array}$ & $\begin{array}{l}\text { nehéz megítélésü: sok } \\
\text { figyelembe veendő tényező } \\
\text { és bonyolult kapcsolatrend- } \\
\text { szer a résztevők között }\end{array}$ \\
\hline Érdekek & egyéni, szubjektív érdekek & $\begin{array}{l}\text { közérdek, vagy legalábbis } \\
\text { emberek nagyobb csoportjá- } \\
\text { nak racionális érdekei }\end{array}$ \\
\hline Megoldási lehetőségek & $\begin{array}{l}\text { neöben és tartalmilag } \\
\text { követhetőek }\end{array}$ & $\begin{array}{l}\text { nehen követhető és } \\
\text { kivelezhető, komplex } \\
\text { megoldások }\end{array}$ \\
\hline
\end{tabular}

25 A Verwaltungsgerichtsordnung 173. § alapján alkalmazandó a Zivilprozessordnung 278. § (5) bekezdése.

26 Opperman, Bettine-LANger, Kerstin: Umweltmediation in Theorie und Anwendung. Akademie für Technikfolgenabschätzung in Baden-Württemberg, Stuttgart, 2000, 13-14. 


\begin{tabular}{|l|l|l|}
\hline \multicolumn{1}{|c|}{ Vizsgálati szempont } & Hagyományos konfliktusok & \multicolumn{1}{|c|}{ Környezeti konfliktusok } \\
\hline Megoldási javaslatok hatásai & elörelátható & $\begin{array}{l}\text { absztrakt és csak } \\
\text { modellezhető }\end{array}$ \\
\hline Érintettek száma & általában kettő & nagyszámú \\
\hline Hatalmi viszonyok & szimmetrikus & aszimmetrikus \\
\hline Alkalmazandó jog & polgári jog & $\begin{array}{l}\text { komplex jogi helyzetek, } \\
\text { több jogág }\end{array}$ \\
\hline Eljárás & tartalmilag és eljárásilag & $\begin{array}{l}\text { eljárásilag komplex, az eljá- } \\
\text { rás hosszának, tárgyának és } \\
\text { a résztvevők nagy számának } \\
\text { következtében }\end{array}$ \\
\hline Megoldás & átlátható & „nyertes-vesztes” is lehet \\
\hline
\end{tabular}

A környezetvédelmi közvetítés, akárcsak a hagyományos közvetítői eljárás, a felek bizalmi viszonyára és a titkosság elvére épül. A titkosság elve ebben a körben a közvetítői eljárások átláthatóságának hiányát, illetve korlátozott voltát jelenti, az abban részt nem vevő harmadik személyek számára. Nem szorul különösebb magyarázatra, hogy a résztvevők nagy száma, mely ebben a körben adott esetben több száz, sőt több ezer résztvevőt is jelenthet, nem szolgálja a bizalmasság és titkosság követelményeinek érvényesülését. Ebböl következik, hogy az eljárásban nem vehet részt minden egyes érdekelt fél személyesen, és így felmerül a képviselet elve. Ez az első „akadály” gyakran az utolsó is, hiszen nehéz feladat a megfelelő számú képviselö kiválasztása. A képviselök kiválasztása különösen nagy kihívást jelent, amikor szakértelmet kívánó, speciális kérdések kerülnek megvitatásra. Figyelni kell egyúttal arra is, hogy hatékonysági okokból huszonöt fónél nem ideális több résztvevővel közvetítést kezdeményezni, mivel a képviselök nagy száma a munkamenetet lassíthatja. ${ }^{27}$

A környezetvédelmi közvetítés kapcsán felmerülö következő problémakör a megválasztott képviselök mandátumához kapcsolódik. Mandátum alatt azt kell érteni, hogy egy adott képviselö milyen szintű cselevési felhatalmazással rendelkezik. A környezetvédelmi közvetítés során fontos, hogy a felek megfelelő mandátumokkal rendelkezzenek, ugyanis gyakran olyan kérdések is felmerülnek, melyek eredetileg nem szerepeltek a „napirenden”. Ekkor a folyamatos visszacsatolások hátráltatják az eljárás lefolytatását. Tipikusan kötött mandátummal rendelkeznek a hatóságok képviselői, akiket mind a delegáló szerv utasításai, mind a jogszabályi követelmények kötnek. Ez alapján elmondható, hogy a környezetvédelmi közvetítői eljárás sikerességének alapvető követelménye az, hogy tisztázott és biztosított legyen a megfelelő szintű mandátum. ${ }^{28} \mathrm{Ez}$ azonban egy nagyon kényes dolog, hiszen fennáll annak a veszélye, hogy a képviselő már nem a képviselt érdekének megfelelően jár el, és a képviselt nem fogadja el a közvetítői eljárás eredményeképpen születő megállapodást. ${ }^{29}$

27 FluCher-KochendöRfER-MINCKWITZ-VIERING: i. m., 99.

28 Opperman-Langer: i. m., 14.

29 Petersen-Zschiesche: i. m., 29. 
A soron következő, részben már érintett specifikum, az eljárásban részt vevő hatóságok speciális helyzetéből adódik. A polgári jogi viták feloldására szolgáló hagyományos közvetítői eljárásban hatóságok aligha vesznek részt. Ez a környezetvédelmi közvetítői eljárásra már nem feltétlenül igaz. A környezetvédelmi közvetítés során ugyan félként szerepelhetnek a hatóságok, de más szabályok vonatkoznak rájuk. Az említett jogszabályi kötöttségeken ${ }^{30}$ felül olyan további elvárásoknak is meg kell felelniük, mint az egyenlő bánásmód vagy az arányosság követelményei. Fontos az is, hogy nem hagyhatnak jóvá olyan intézkedéscsomagot, mely nincs összhangban más szervek és hatóságok érdekeivel. Ezek a körülmények nyilvánvalóan nehezítik a környezetvédelmi közvetítés lefolytatását.

A következőkben a közvetítő személyéröl, illetve a rá vonatkozó szükséges többletkövetelményekröl lesz szó. A környezetvédelmi közvetítés során a felek helyzete korántsem azonos. ${ }^{31}$ A társadalmi szerveződések pozíciója általában szervezeti, anyagi és humánerőforrási oldalról megközelítve sem tekinthető kielégítőnek a nagyvállalatokéhoz képest. ${ }^{32} \mathrm{~A}$ közvetítöknek ezért ezekben a konfliktusokban olyan légkört kell teremteniük, ami biztosítja azt, hogy a felek nyissanak egymás irányába. Fontos, hogy a közvetítő biztosítsa a feleket arról, hogy az érdekeik megfelelö súllyal esnek latba. Figyelni kell azonban arra, hogy az eljárás során ők nem döntőbírók, akik saját megoldásokat és döntési javaslatokat terjeszthetnének a felek elé. Szintén nem szabad, hogy szakértői vagy tanácsadói szerepben tündököljenek, így szakkérdés felmerülése esetén külső szakértő bevonása szükséges. ${ }^{33} \mathrm{~A}$ vita megoldására vonatkozó felelősség egyedül a feleket kell hogy terhelje. Azonban a felek döntési autonómiája nem értelmezhető úgy, mint a hagyományos közvetítői eljárás során. Ezekben az esetekben a résztvevők inkább a döntések előkészítését és kialakítását befolyásolhatják, mely döntések végső soron politikai és hatósági hatáskörbe tartoznak. A környezetvédelmi közvetítés elsősorban „minőségibb” eljárásra ad lehetőséget, mely eljárás eredménye egy jobb és társadalmilag elfogadhatóbb megoldás lehet. A konfliktus lényegének feltárásához a közvetítőnek gyakran széles körü ismeretekkel kell rendelkeznie. Az adott vita tárgyától függően ilyen ismeret lehet például a müszaki, gazdasági, társadalmi vagy jogi ismeret. Ennek megfelelően a környezetvédelmi közvetítés során a jogászi végzettség nem szükségszerü követelmény a közvetítő oldalán. ${ }^{34}$ A szükséges szakterületeken legalább annyi jártasság szükséges, amennyi nélkülözhetetlen a megbeszélések strukturálásához, illetve ahhoz, hogy a közvetítő megfelelő kérdéseket tudjon feltenni a felek számára. Azon területekre, ahol a környezetvédelmi közvetítés alkalmazásra kerül, jellemző, hogy a politika és a közszféra eljárási rendje és érdekei érvényesülnek. A közvetítőnek ezért szükséges ezeket az eljárásokat és érdekeket ismernie.

30 http://www.umweltwissenschaften.de/fileadmin/PDF/M11_KE1_Mediation_im_oeffentlichen_Bereich_ Teil_1.pdf (2016. 11. 02.).

31 http://www.vivis.de/phocadownload/2011_is/2011_IS_273_284_Hehn.pdf (2016. 11. 19.).

32 Petersen-Zschiesche: i. m., 28.

33 Petersen-Zschiesche: i. m., 27.

34 http://www.umweltwissenschaften.de/fileadmin/PDF/M11_KE1_Mediation_im_oeffentlichen_Bereich_ Teil_1.pdf (2016. 11. 02.). 
Fontos különbség a hagyományos közvetítéshez képest, hogy a legtöbb környezetvédelmi közvetítői eljárást a közhatalmi szervek rendelik el, és ők is finanszírozzák. A konfliktus tárgyától függően a finanszírozó lehet például egy helyi önkormányzat, szövetségi tartomány vagy akár egy minisztérium is. ${ }^{35} \mathrm{~A}$ legösszetettebb közvetítői eljárások igen magas költségűek. Az ügyben eljáró közvetítői irodát, illetve közvetítőt egy közbeszerzési eljáráshoz hasonló eljárásban választják ki, amelynek során a hatóság felvázolja az esetet, és megversenyezteti az ajánlattevőket. A hagyományos közvetítői eljárás az előzőekkel szemben mindig a vitában érintettek kezdeményezésére indul.

Az eljárásban való részvétel önkéntessége más megvilágításba kerül a környezetvédelmi közvetítés során. ${ }^{36}$ Nem kötelező ugyan részt venni az eljárásban, de a távolmaradás több okból problémás. Egyrészről a távolmaradás nyilvánvalóan nem áll az eljárástól elzárkózók érdekében, annak ellenére sem, hogy az eljárás kezdetén bizonyos dolgokkal nem értenek egyet. Másrészről problémás azért is, mert a távolmaradók valószínüleg nem fogják elfogadni a születő döntést, és később a közigazgatási bíróság előtt megtámadják azt. ${ }^{37}$

A közvetítés alapötlete nem más, mint az, hogy a születő megállapodással minden részt vevő fél elégedett legyen, és nyertesnek érezze magát („nyertes-nyertes” helyzet). Ennek a követelménynek a környezetvédelmi közvetítés nem minden esetben tud megfelelni, és általánosságban elmondható, hogy a nagyszámú résztvevő közül mindig akad olyan, aki az eljárás végén vesztesnek érzi magát.

Ha a közvetítöi eljárás költségvonzatáról beszélünk, elmondhatjuk, hogy a hagyományos közvetítői eljárás jellemzően alacsony költségekkel járó vitarendezési mód. A környezetvédelmi közvetítés ezzel szemben korántsem olcsó: az eljárás lefolytatásával közvetlenül összefüggő költségeken kívül egyéb kiadások is felmerülhetnek, így a többi fél meggyőzésével felmerülő költségek vagy a résztvevők díjai. ${ }^{38}$ Különösen igaz ez akkor, amikor nem kormányzati szervezetek vesznek részt az eljárásban, hiszen egy szervezet, melynek a környezetvédelem a feladata, nehezen győzhető meg, és mindig teljesítési kényszer nehezedik rá. ${ }^{39}$

A hagyományos közvetítői eljárások során kötött megállapodásokat, amennyiben azok a jogszabályi követelményeknek megfelelnek, okiratba foglalják, és kötelező erővel ruházzák fel. A környezetvédelmi közvetítés során született megállapodás kötelező erővel nem bírhat, hiszen a környezetvédelmi közvetítés a jelenlegi szabályozás szerint mindig egy másodlagos eljárásnak tekinthető. Ez azt jelenti, hogy a tényleges döntést egy másik, például hatóság előtt zajló engedélyezési eljárásban hozzák meg.

35 http://www.umweltwissenschaften.de/fileadmin/PDF/M11_KE1_Mediation_im_oeffentlichen_Bereich_ Teil_1.pdf (2016. 11. 02.).

36 http://www.umweltwissenschaften.de/fileadmin/PDF/M11_KE1_Mediation_im_oeffentlichen_Bereich_ Teil_1.pdf (2016. 11. 02.).

37 Petersen-Zschiesche: i. m., 27.

38 Petersen-Zschiesche: i. m., 28.

39 WeIDNER, Helmut: Im Südwesten nichts Neues. Wissenschaftszentrum Berlin, Mitteilungen, Berlin, $2011,327$. 


\subsection{Az eljárás szakaszai}

A környezetvédelmi közvetítés nagy vonalakban a hagyományos közvetítéshez hasonlóan zajlik a gyakorlatban. ${ }^{40} \mathrm{Az}$ eljárás során egy kerekasztal-beszélgetés történik, ahol a különböző érdekeket képviselők vesznek részt. Attól függően, hogy mennyire bonyolult ügyröl van szó, illetve hogy mennyire kell speciális szakértelem az ügy megítéléséhez, esetlegesen munkacsoportok szerveződnek, akik a vita egy meghatározott speciális szegmensére dolgoznak ki megoldást. Ha az emberek nagyobb csoportját érinti a kérdés, például egy város teljes lakosságát, akkor sor kerülhet nyilvános workshopok megrendezésére, ezzel növelve a születő döntés össztársadalmi legitimációját. ${ }^{41}$

Ha közelebbről megvizsgáljuk az eljárást, láthatjuk, hogy hat egymástól elkülöníthető szakaszra oszlik. ${ }^{42}$

Az első szakasz a felek kapcsolatba lépésétől a közvetítői szerződés megkötéséig tart. Ennek az előzetes egyeztetésnek a célja annak megállapítása, hogy az adott ügy alkalmas-e arra, hogy környezetvédelmi közvetítői eljárást folytassanak le benne. Ebben a szakaszban „ismerkednek” meg továbbá az eljárás résztvevői egymással, illetve egymás helyzetével. A résztvevők ekkor juttatják kifejezésre akaratukat és határozzák meg elvárásaikat a környezetvédelmi közvetítéssel kapcsolatosan. Nagyon fontos eltérés a hagyományos közvetítői eljáráshoz képest, hogy amíg azokban az eljárás eme előkészítő szakaszában nem vagy kevés szó esik a konfliktus tartalmát képező érdemi kérdésekröl, addig a környezetvédelmi közvetítés során a problémás kérdések igen részletesen megvitatásra kerülnek. Ennek magyarázata az, hogy a közvetítő vagy közvetítő csapat előtt nem ismertek a konfliktus részletei, miközben a környezetvédelmi közvetítés átfogó előkészítést igényel, és ezért szükséges bizonyos kérdések minél korábbi tisztázása. A pártatlanság elvéből adódóan ideális esetben minden fél lehetőséget kap arra, hogy a konfliktust a saját szemszögéből ismertesse. Ez hozzájárul ahhoz is, hogy a felek jobban megismerjék egymás érdekeit és hozzáállását a konfliktushoz. Mivel az eljárás résztvevői, mint ahogyan arról már korábban volt szó, általában emberek nagyobb csoportját képviselik, ezért szükséges ebben az eljárási szakban a visszacsatolási mechanizmusok tisztázása is. ${ }^{43} \mathrm{Az}$ első szakasz lezárásaként születő közvetítői szerződésben olyan kérdések kerülnek tisztázásra, mint az eljárás alapja és célja, valamint a közös munka összehangolásának technikai kérdései. Szabályozásra kell hogy kerüljön a költségek viselésének kérdése is, hiszen erre vonatkozóan nincs semmiféle jogszabályi előírás. Az önkéntesség elvéből következik, hogy a szerződést minden résztvevőnek alá kell írnia. Fontos az is, hogy a közvetítő bérmegállapodását is minden fél aláírja, mivel a közvetítő finanszírozásában részt nem vevő félre, illetve felekre nem vonatkozik a megállapodás. ${ }^{44}$

40 Opperman-Langer: i. m., 28.

41 https://www.mediationaktuell.de/news/mediation-im-oeffentlichen-bereich (2016. 11. 10.).

42 FüRST, Gerhart Conrad: Umweltmediation. Methoden - Verfahren - Lösungswege für Entscheidungsträger und Mediatoren. Manz Verlag Wien, Wien, 2004, 75.

43 http://www.partizipation.at/fileadmin/media_data/Downloads/Forschungsplattform/MasterThesis_ Flughafenmediation_12_11_2011.pdf (2017.02. 20.).

44 http://static.springer.com/sgw/documents/1361050/application/pdf/w_44_5797.pdf (2017. 02. 20.). 
A második eljárási szakaszban kerül sor a megvitatandó témák kiválasztására. Fő szabály szerint akkor kerülhet sor egy adott téma "felvételére”, ha az illeszkedik az eljárás első szakaszában meghatározott, közös célokhoz. Az eljárás sikere érdekében ebben a szakaszban minden résztvevőnek fel kell fednie valós akaratát. Fontos továbbá, hogy a témák meghatározása kellően semleges legyen, hogy minden résztvevő elfogadja azokat anélkül, hogy már az eljárás elején kényszerü kompromisszumok születnének. A téma, illetve témák meghatározása kapcsán ügyelni kell arra is, hogy az adott kérdésben születendő megállapodás megvalósítható is legyen. Az eljárás folyamán a választott témakörökben lehetőség van a módosításokra. ${ }^{45}$

A harmadik eljárási szakaszban a konfliktus lényegének feltárása történik. Ez a szakasz akkor tekinthető sikeresnek, ha a felek késznek mutatkoznak arra, hogy a többi résztvevő álláspontját is figyelembe vegyék. ${ }^{46} \mathrm{Az}$ azonban természetesen nem szükséges, hogy a másik fél érdekeit a sajátjukkal szemben előnyben részesítsék. A cél az, hogy a felek megértsék egymás helyzetét és érdekeit.

Az eljárás következő szakaszában a felek megoldási lehetőségeket dolgoznak ki. A „fantáziának” ebben a körben a megvalósíthatóság szab határt. Olyan lehetséges megoldási módozatok is szóba kerülhetnek, melyek ugyan csak az egyik félnek elönyösek, azonban a többi fél kompenzálódik azáltal, hogy a megvalósítás ebben a körben számukra nem jár költségekkel. Ezen eljárási szak fontos feladata továbbá, hogy feltérképezze azokat a lehetséges megoldásokat, melyeket minden fél elutasit. ${ }^{47}$

Az ötödik eljárási szakban a megoldási lehetőségek értékelése következik. Fontos ebben a körben, hogy az értékelés megkezdése elött objektív kritériumokban kell megállapodnia a feleknek, melyek mentén az értékelés zajlik. A környezetvédelmi közvetítés már érintett sajátossága, hogy a megoldások megvitatásához szükséges ismereteknek a felek gyakran nincsenek birtokában, ezért külső szakértők bevonása válik szükségessé. Ideális esetben a felek közös megegyezéssel jelölik ki ezeket a szakértőket, illetve az eljárásban részt vevő tanácsadókat. Jelen eljárási szakasz következő lépése az, hogy a felek kijelölik azokat a megoldási lehetőségeket, amelyek mindannyiuk számára kedvezőek vagy legalább elfogadhatóak. Ki kell zárni azokat a verziókat, melyek egyes csoportok érdekeit egyértelmüen sértik. Mindezek után meg kell vizsgálni, hogy az egyes kérdésekre vonatkozó megoldási variációk hogyan illeszthetők össze egy kivitelezhető javaslattá. ${ }^{48}$

Az eljárás utolsó szakaszában kerül sor a tárgyalásra, vagy ha szükséges, tárgyalásokra. Ebben az eljárási szakban állapodnak meg a felek egymással, és kerül sor a megállapodás gyakorlatba való átültetésére is. ${ }^{49} \mathrm{Azt}$, hogy a közvetítés eredményeképpen születő megállapodást milyen formában rögzítik, és annak milyen jogi kötőereje lesz, a közvetítői eljárás megindulásakor kötendő közvetítői szerződés rendezi. Ebben a szerződésben ideális továbbá szót ejteni arról, hogy a gyakorlati megvalósítás megállapodásszerủ végrehajtását milyen ellenőrzési mechanizmusok

45 http://static.springer.com/sgw/documents/1361050/application/pdf/w_44_5797.pdf (2017. 02. 20.).

$46 \mathrm{http}: / /$ www.partizipation.at/fileadmin/media_data/Downloads/Forschungsplattform/MasterThesis_ Flughafenmediation_12_11_2011.pdf (2017. 02. 20.).

47 Fürst: i. m., 81.

48 http://www.partizipation.at/fileadmin/media_data/Downloads/Forschungsplattform/MasterThesis_ Flughafenmediation_12_11_2011.pdf (2017. 02. 20.).

49 Fürst: i. m., 84. 
biztosítják. Mint arról már korábban esett szó, a környezetvédelmi közvetítés kapcsán nem reális cél az, hogy minden kérdésben egyetértés, illetve megállapodás szülessen. Az előzőből következik, hogy sikerként értékelendő már az is, ha csak részben sikerül konszenzusra jutni. Nem szabad elfelejteni azt sem, hogy a döntési autonómia a hatóságok birtokában van, így a környezetvédelmi közvetítés eredménye csupán javaslat, amit a tényleges döntés meghozatala során figyelembe vehetnek a hatóságok.

\section{Esettanulmányok}

Az alábbiakban két eseten keresztül szemléltetem a környezetvédelmi közvetítés gyakorlatát, rávilágítva annak problémáira is. A választott esetek talán a német gyakorlat legismertebb esetei. Mind a kettő alkalmas arra, hogy a környezetvédelmi közvetítés alkalmazásának egyes kérdéseit, problémáit szemléltesse. Delegációs és képviseleti problémák, az eljárástól elzárkózók és utólagosan elégedetlenkedők kérdése, a megállapodás kötelező erejének problémája és így tovább. Habár mindkét eljárás sikertelennek tekinthető abból a szempontból, hogy az eredményük nem került teljes mértékben átültetésre, látni fogjuk, hogy mégis több szempontból eredményesnek tekinthetők.

\subsection{A frankfurti reptér esete}

\subsubsection{Az esetröl}

A frankfurti reptér Európa legnagyobb teher-, és második legnagyobb utasforgalmat lebonyolító reptere. ${ }^{50}$ Annak érdekében, hogy a forgalom „természetes” növekedését ki tudja szolgálni, már 1997-ben felmerült egy új felszállópálya építése. Legutoljára 1984-ben bővítették a repteret, de sem az emberek, sem a reptér üzemeltetője nem felejtették el az esetet. Az akkori bővítés körül rendkívül heves viták zajlottak, már-már „polgárháborús” állapotok alakultak ki. ${ }^{51} \mathrm{~A}$ két bővítési hullám mögött meghúzódó indokok és érdekek azonosak voltak. A bővítést támogatók azzal érveltek, hogy az egész térség gazdasága profitál majd a fejlesztésből. A bővítést ellenzők szintén igen erős érveket tudtak, mivel számos olyan környezeti vonatkozású probléma merül fel, mint a zaj és károsanyag-kibocsátás növekedése, valamint a felszállópálya kialakításához szükséges területröl történő fakivágás. Kormányzati intézkedés eredményeképpen az ügyet környezetvédelmi közvetítésre utalták, mely eljárásban huszonegy érdekcsoport képviselői és három közvetítő vett részt. ${ }^{52} \mathrm{Az}$ eljárás céljaként azt határozták meg, hogy állapítsa meg, milyen módon valósítható

50 http://www.forum-flughafen-region.de/fileadmin/files/Archiv/Archiv_Mediation-Dokumentation/ Dokumentation_Mediation_Frankfurt_Leitfaden_2000.pdf (2016. 11. 16.).

51 http://www.forum-flughafen-region.de/fileadmin/files/Archiv/Archiv_Mediation-Dokumentation/ Dokumentation_Mediation_Frankfurt_Leitfaden_2000.pdf (2016. 11. 16.).

52 GeIS, Anna: Umstritten aber Wirkungsvoll: Die Frankfurter Flughafen Mediation. HSFK-Report, 2003/13, 10. 
meg a gazdasági szempontból nélkülözhetetlen fejlesztés a lehető legkisebb mértékü környezeti beavatkozással. Egy kivételével azonban minden helyi érdekcsoport és környezetvédelmi szervezet elhatárolódott a részvételtől, mivel ők azt akarták, hogy egyáltalán ne valósuljon meg a fejlesztés. Az eljárásban való részvételtől elzárkózók olyan érveket hoztak fel távolmaradásuk magyarázataként, minthogy a közvetítők elfogultak, és hogy nem tényleges egyeztetésekről van szó, hanem egy puszta utólagos jóváhagyásról. ${ }^{53}$ A részvétel pedig nem kényszeríthető ki, hiszen az ideális környezetvédelmi közvetítés kiindulási alapja az önkéntesség. ${ }^{54}$

A környezetvédelmi közvetítői eljárás eredménye végül egy intézkedési csomag lett, melynek alapján a fejlesztés (2011-re) megvalósulhatott, azonban optimalizálták a meglévő kifutókat, betiltották az éjszakai járatokat, és zajvédelmi berendezéseket szereltek fel. ${ }^{55}$ Mivel a megállapodás jogilag nem kötelező érvényű, ezért az azzal elégedetlen „vesztes” résztvevők és az eljárástól távol maradók el is utasították azt. Ebben a körben kiemelendő, hogy a reptér üzemeltetői az éjszakai járattilalomról hallani sem akartak. Jól jellemzi az állapotot az akkoriban elhangzott kijelentés: „vége a közvetítésnek, kezdődhet a veszekedés”. ${ }^{66}$ Az eljárás sikertelenségének hátterében pedig paradox módon azok a helyi érdekképviseleti csoportok és környezetvédő szervezetek álltak, akiknek érdekében állt volna a részvétel az eljárásban, tekintettel annak jelen tanulmányban ismertetett jellemzőire és céljaira.

\subsubsection{A közvetítői eljárás értékelése}

Az eset kapcsán kétségtelenül pozitív eredményként értékelendő, hogy született egy megállapodás, melynek hátterében egy bizonyos fokú konszenzus állt. Nagyban növeli továbbá az eljárás pozitív megítélését, hogy valamennyi aspektusa felmerült a bővítésnek, olyanok is, melyekről egy hagyományos döntéshozatali eljárás során nem esett volna szó. Érdekes álláspont, hogy az a körülmény, hogy a sorozatos konfliktusok eredményeképpen a nyilvánosság felfigyelt a bővítés kapcsán felmerült kérdésekre, nagyobb értéket hordoz magában, mint magának a problémának a megoldása. ${ }^{57} A$ környezetvédelmi közvetítés eredményeképpen születő megállapodáscsomag megállapításai ugyan nem bírnak kötelező erővel, azonban bekerültek a tartományi fejlesztési terv preambulumába, mint célok, illetve egyfajta elvi iránymutatások. ${ }^{58} \mathrm{~A}$ környezetvédelmi közvetítést követő hatósági eljárás során pedig a megállapodás egyes elemeire hivatkoztak az eljárás résztvevői. Ebben a körben kiemelendő, hogy gyengíti a távolmaradó környezetvédő csoportok hite-

53 GeIs, Anna: Regiren mit Mediation - Das Beteiligungsverfahren zur zukünftigen Entwicklung des Frankfurter Flughafens. Vs Verlag für Sozialwissenschaften, Wiesbaden, 2005 [a továbbiakban: GeIs (2005)], 19.

54 Vossebürger, Petra-Claus, Fran: Ablauf von Mediationsverfahren. Förderverein Umweltmediation e.V., Bonn, 1999, 85.

55 GeIs, Anna: Mediation. Verhandlungen im öffentlichen Bereich. In: Kersting, Norbert (szerk.): Politische Beteiligung. VS Verlag für Sozialwissenschaften, Weisebaden, 2008 [a továbbiakban: GEIS (2008)], 202.

56 http://www.gruene-hessen.de/frankfurt/ (2016. 11. 18.).

57 Bingham, Gail: Resolving Environmental Disputes. A Decade of Experience. The Conservation Foundation, Washington, D.C., 1986, 66.

58 GeIS (2008): i. m., 203. 
lességét, és egyúttal az eljárás eredményességét erősíti, hogy még a részvételtől elzárkózók is hivatkoztak a környezetvédelmi közvetítői eljárás eredményeképpen létrejött megállapodás zajcsökkentéssel kapcsolatos rendelkezéseire. ${ }^{59} \mathrm{Az}$ eljárás negatívumaként értékelhető azonban, hogy a kezdeti problémafelvetés kapcsán nem alakult ki egységes álláspont, ezért nem minden érintett vett részt, akik a későbbiek során nem is ismerték el a megállapodást, tehát a született megállapodás elfogadottsági szintje nem volt kielégítő. ${ }^{60}$

\subsubsection{Az eljárás sikertelenségének okai}

A környezetvédelmi közvetítői eljárás sikertelenségének hátterében több ok húzódik meg. Vizsgálandó ebben a körben a felek viszonya, amiröl elmondható, hogy a hatóságok és a környezetvédő érdekcsoportok kapcsolatát a bizalmatlanság jellemzi. Különösen igaz ez jelen esetben, ahol a felek szemében a reptér 1984-es bővítésének kellemetlen eseményei látszódtak megismétlődni. A környezetvédelemmel foglalkozó szervezetek úgy vélték, hogy a hatóságok problémamegoldási képessége és akarata nem kielégítő, ezért megtagadták az eljárásban való részvételt. ${ }^{61}$ Úgy vélték, hogy gyenge helyzetben vannak jogilag és egyéb szempontokból is a hatóságokkal szemben, és nem akartak lemondani az elégedetlenség kifejezésének „,hagyományos eszközeiről”, mint például a nyilvános tiltakozások szervezése. Sokan azért utasították el a környezetvédelmi közvetítői eljáráson való részvételt, mert azt a központi kormányzat rendelte el, és nem önkéntes alapon indult. ${ }^{62}$

Látni kell jelen ügy kapcsán azt is, hogy a megállapodáscsomag nem teljes, mivel maradtak nyitott kérdések, mint az új kifutó pontos helye, vagy a zajcsökkentő berendezések és az éjszakai járattilalom körüli kérdések kidolgozása. ${ }^{63} \mathrm{~A}$ megoldási javaslat kidolgozatlansága is hivatkozási alapul szolgált az átültetést ellenzők számára.

Problémát jelent még az is, hogy a közvetítői eljárás eredményeképpen született megállapodás jogilag nem kényszeríthető ki. Fontos azonban látni azt is, hogy a kívánt kikényszeríthetőség ára a részletes jogi szabályozottság lenne, ami azonban sztenderdizációhoz vezethet. A sztenderdizáció pedig pont a környezetvédelmi közvetítés lényegi elemeivel ellentétes, különösen a nyitottsággal és rugalmassággal. Az eljárás során továbbá a politika túlzott mértékben volt jelen, ami korlátozta az eljárás nyitottságát, illetve behatárolta a lehetséges eredményeket.

59 GoHL-Hans: i. m., 103.

60 http://www.forum-flughafen-region.de/fileadmin/files/Archiv/Archiv_Mediation-Dokumentation/Dokumentation_Mediation_Frankfurt_Leitfaden_2000.pdf (2016. 11. 16.).

61 HolzInger, Katharina: Evaluating Environmental Mediation: Mediation in the Waste Management Programme of Neuss County, Germany. Results of a Participant Survey. Wissenschaftszentrum Berlin für Sozialforschung, Berlin, 1997, 2-3.

62 GeIS (2005): i. m., 18.

63 GEIS (2008): i. m., 202. 


\subsection{Stuttgart 21}

\subsubsection{Az esetröl}

A stuttgarti vasútállomás felújításának, illetve átalakításának tervét először 1994ben hozták nyilvánosságra. Az átalakítás hátterében az húzódott meg, hogy a 19. században épült monumentális fejpályaudvarok a 20 . század végére egyre inkább elavultnak számítottak. ${ }^{64}$ A tervcsomag a Bahnhof 21 nevet kapta, ahol a szám a 21. századot jelenti. Innen ered a Stuttgart 21 elnevezés, mely a Stuttgart városában tervezett átalakításokat jelöli. ${ }^{65}$ Ezen a ponton megjegyzem, hogy a szakirodalom felváltva használja a szóban forgó eset kapcsán a környezetvédelmi közvetítés (Umweltmediation) és a döntőbíráskodás (Schlichtung) szavakat. Jelen esetben, az eljárás lényegi elemeit vizsgálva sokkal inkább környezetvédelmi közvetítésről van szó, hiszen az eljárást vezető nem volt döntési pozícióban, ami nélkülözhetetlen jellemzője a döntőbíráskodásnak.

Mikor 2010 februárjában meg kívánták kezdeni a kivitelezési munkálatokat, a lakosság heves tiltakozásba kezdett. ${ }^{66}$ Külön említést érdemel, hogy a felújítási projekt már korábban „átment” minden demokratikus érdekegyeztetési fórumon. Nem túlzás azt állítani, hogy a város joggal érezhette úgy, hogy minden szempontból jogosult megkezdeni a munkálatokat.

Miután a tüntetések nem hagytak alább, az ügy közvetítői eljárásra utalásáról döntöttek. A közvetítői eljárásban összesen tizenheten vettek részt, illetve egy közvetítő. ${ }^{67}$ A 2010 októberétől 2010 novemberéig megtartott, összesen kilenc ülésen olyan témák voltak terítéken, mint a projekt gazdasági jelentősége, alternatívák keresése és a környezeti hatások vizsgálata. A közvetítői eljárás során tisztázandó kérdések igen komplexek voltak, és széles körü bizonyítási eljárás lefolytatását igényelték. A német vasúttársaság kötelezettséget vállalt arra vonatkozóan, hogy egy szimulációs program segítségével modellezi azt, hogy a tervezett beruházás eredményeképpen harmincszázalékos forgalomnövekedés válik elérhetővé a közlekedés minőségének romlása nélkül. Ennek a szimulációnak a célja az elérhető gazdasági növekedés konkrét adatokkal való alátámasztása volt. A projekt másik eleme egy teljesen új pályarendszer kialakítása Ulm irányában. Ennek az új vasúti pályának a kivitelezése, illetve az egyéb szükséges átalakítások rengeteg fa kivágását teszik szükségessé, és a zajterhelés is szükségszerüen nő az új nyomvonal miatt. Szintén részletesen vizsgálták azt, hogy miként lehet csökkenteni az előzőek mértékét. Mivel az állomás, illetve a sínpályák egy része a föld alá kerül, a felszabaduló területek, ingatlanok sorsáról is sok szó esett. A lakosság és a környezetvédők igénye az volt,

64 http://vonattal-termeszetesen.blog.hu/2014/09/12/a_stuttgart (2017. 01. 10.).

65 A Stuttgart 21 egy tervezett közlekedés- és városfejlesztési projekt, amely a stuttgarti vasúti csomópont teljes átépítését és újjászervezését tartalmazza. A Wendlingen-Ulm nagy sebességü vasútvonallal együtt hivatalosan Bahnprojekt Stuttgart-Ulmnak nevezik a projektet.

66 http://www.spiegel.de/politik/deutschland/mappus-stuttgart-21-erklaerung-schwaetza-schwaetza-bahnhofbaua-a-721673.html (2016. 11. 18.).

$67 \mathrm{http}: / /$ www.spiegel.de/politik/deutschland/mappus-stuttgart-21-erklaerung-schwaetza-schwaetza-bahnhofbaua-a-721673.html (2016. 11. 18.). 
hogy kerüljön kialakításra minél több park ezeken a területeken. Kérték továbbá azt is, hogy a felszabaduló területeken épülő lakások ára ne legyen eltúlzott. ${ }^{68}$

A közvetítés eredményeképpen végül egy Frieden in Stuttgart elnevezésü programterv született. A terv legfontosabb eredménye az, hogy az új állomás kombinált kialakítású lesz. Ez azt jelenti, hogy a távolsági vonatok a föld alatt közlekednek, a tartományi járatok meg a föld felszínén. Ezen túlmenően egyes vágányok megőrzik a fejpályaudvari jelleget, míg a többi tranzitvágányként szolgál majd. ${ }^{69}$ A programterv alapján a vasútállomás feletti rész zöldövezetté válik. A projekt kivitelezését a közvetítést követően meg kívánták kezdeni, azonban ismét heves tiltakozások következtek be, mivel a lakosság megpróbálta a Stuttgart központjában elhelyezkedő tér, a Schlossgarten területén megakadályozni a fakivágásokat. Végül a projekt megvalósítását évekkel később kezdték el, és véglegesen csak 2022-re fejezik be.

\subsubsection{A közvetítői eljárás értékelése}

Álláspontom szerint jól látszik, hogy a környezetvédelmi közvetítés folyamatos és gyors fejlődésen megy át. A frankfurti reptér esete óta alig több mint öt év telt el, ennek ellenére sok pozitív változás volt tapasztalható a Stuttgart 21 ügyében. Egyrészről nem voltak már delegációs problémák, és a meghívottak sem zárkóztak el a részvételtől. Másrészről az eljárás során sokkal érdemibb kérdések kerültek megvitatásra, mint a frankfurti reptér esetében.

A környezetvédelmi közvetítés eredményeképpen született megállapodás nem kötelező erejü, azonban az eljárás ennek ellenére sem tekinthető sikertelennek. Az eljárás eredményeként ugyanis a projekt kivitelezése zöldebb úton halad, és összességében a lakosság is jobban elfogadja azt. Így el lehet mondani, hogy a környezetvédelmi közvetítői eljárás elérte a célját azzal, hogy magasabb színvonalú, társadalmilag elfogadottabb döntés született. Az eljárás érdemét növeli továbbá, hogy jogi kötőerő hiányában is, sokan felhívták a későbbiekben a megállapodásban foglaltakat. $^{70}$

\subsubsection{Az eljárás sikertelenségének okai}

Az eljárás sikertelenségének hátterében álláspontom szerint három ok áll. Egyrészről az, hogy a német kormány mindenáron meg akarta valósítani a projektet, mégpedig a saját elképzelései szerint. Erre pedig jó oka volt, hiszen ebben az időben több nagyváros is, mint Zürich vagy Salzburg, hasonló fejlesztéseket hajtott végre, amiből igen sokat profitáltak. Ezt a körülményt a környezetvédelmi közvetítői eljárás többi résztvevője pontosan tudta, így csökkent az eljárás hitelessége, illetve az annak érdemi voltába vetett bizalom. Másrészröl akadályozó tényező volt a dön-

68 http://www.schlichtung-s21.de/fileadmin/schlichtungs21/Redaktion/pdf/101130/2010-11-30_Schlichterspruch_Stuttgart_21_PLUS.pdf (2016.11.18.).

69 http://www.schlichtung-s21.de/fileadmin/schlichtungs21/Redaktion/pdf/110729/frieden_in_stuttgart.pdf (2016. 11. 18.).

$70 \mathrm{http}: / / g e a . d e /$ nachrichten/politik/stuttgart+21+buendnis+geht+gegen+baumfaellarbeiten+vor.2421253.htm (2016. 11. 05.). 
tés kötelező erejének hiánya. A közvetítő már a megbeszélések kezdetén leszögezte, hogy nem vitás az, hogy a közvetítői eljárás eredményeképpen nem jöhet létre jogilag kötelező erejü megállapodás, azonban egyértelműen lesznek politikai következmények. ${ }^{71} \mathrm{Az}$ esetleges kételyeket, miszerint a környezetvédelmi közvetítés eredménye kötelező-e, maga a tartományi bíróság oszlatta el, mikor kimondta, hogy a megállapodás jogilag nem kikényszeríthető. ${ }^{72}$ Harmadrészről pedig a frankfurti esethez hasonlóan itt is voltak elégedetlen „vesztesek”, hiszen nem beszélhetünk jelen esetben sem nyertes-nyertes helyzetröl. ${ }^{73}$

\section{4. Összegzés}

Jelen tanulmány igyekezett rámutatni, hogy a nagy, főként állami beruházások során kialakult környezeti konfliktusok nem kezelhetők egyoldalúan, mivel az szinte mindig katasztrofális következményekhez vezet. Az ilyen kormányzati magatartás ugyanis tüntetéseket, elégedetlenséget és közigazgatási pereket eredményez. Nem meglepő tehát, hogy a jogalkotó régóta új megoldást, illetve eljárásrendet kíván találni annak érdekében, hogy megalapozott és társadalmilag elfogadott döntések szülessenek. Nem szabad azonban túlzottan idealistán sem hozzáállni a közvetítés e területen való alkalmazásához, hiszen az elégedetlenséghez vezet minden olyan esetben, amikor van olyan résztvevő, aki nem teljes mértékben ért egyet az eredményekkel. Ezzel pedig csökken az egyébként értékes és eredményes eljárás megítélése. Figyelemmel kell lenni arra is, hogy jelenlegi formájában a környezetvédelmi közvetítés legfontosabb feladata egy minőségibb döntés elökészítése. Ebben a körben pedig az is eredményként értékelhető, ha bizonyos kérdésekben születik csak megállapodás.

Maga a környezetvédelmi közvetítés célja sem feltétlenül az, hogy minden kérdésben döntés szülessen, hanem az, hogy átláthatóbb eljárás során kerüljenek megvitatásra az emberek nagy csoportját érintő kérdések. ${ }^{74} \mathrm{Az}$ általános várakozás a közvetítés e téren való alkalmazásával kapcsolatosan az, hogy a későbbiekben szélesebb alkalmazást nyer. ${ }^{75}$ A legvégső cél pedig az lehetne, hogy a döntések egy környezetvédelmi közvetítői eljárás keretében lássanak napvilágot.

A környezetvédelmi közvetítés intézményének vizsgálatakor szükséges megvizsgálni annak atipikus vonásait, mely vonásokra jelen tanulmány igyekezett rámutatni. Az eltérő követelményeknek és eljárásrendnek való megfelelés a sikeres környezetvédelmi közvetítés zálogának tekinthető.

71 http://www.schlichtung-s21.de/fileadmin/schlichtungs21/Redaktion/pdf/101130/2010-11-30_Schlichterspruch_Stuttgart_21_PLUS.pdf (2016.11. 18.).

72 http://vgstuttgart.de/pb/,Lde/Klage+der+Stuttgarter+Netz+AG+gegen+den+Abbau+des+Gleisvorfeldes+im +Rahmen+von+S+21++bleibt++ohne+Erfolg/?LISTPAGE=1217876 (2016. 11. 18.).

73 http://www.stuttgarter-zeitung.de/inhalt.stuttgart-21-fuenf-jahre-nach-der-schlichtung-geisslers-umstrittener-schlichterspruch.b63ae571-591d-49c8-8d33-a63ff6c895e1.html (2016. 11. 18.).

74 Opperman-Langer: i. m., 49.

75 Petersen-Zschiesche: i. m., 27. 


\begin{abstract}
It has always been a difficult question for the State to ensure effective decision-making processes for instances where public participation is considered to be a requirement. This question might be even more essential when it comes to disputes concerning large-scale projects with environmental impact. When the public is affected by such project, the contractor must be really prudent, otherwise high number of litigation may be initiated afterwards. The very special form of mediation, the so-called environmental mediation may offer a solution to this problem, by allowing all participants to meet and discuss every crucial issues related to projects described above. It is also important to emphasize that not the same requirements apply to environmental mediation and to other civil law related mediation procedures. The aim of environmental mediation would not be less than to improve the quality of public bodies' decisions.
\end{abstract}

